\title{
Iron Deficiency in Palms ${ }^{1}$
}

Timothy K. Broschat ${ }^{2}$

\section{Symptoms}

Iron $(\mathrm{Fe})$ deficiency appears as interveinal or uniform chlorosis of the newest leaves (Figure 1). Older leaves remain green. In palms suffering from chronic Fe deficiency, the entire canopy may be chlorotic (Figures 4 and 5). In severely Fe-deficient palms, new leaflets may have necrotic tips, growth will be stunted, and the meristem may eventually die (Figure 2). Early symptoms in Syagrus romanzoffiana (queen palm), Rhapis spp. (lady palms), and some Licuala spp. may appear as chlorotic new leaves covered with green spots 2 to 4 $\mathrm{mm}$ in diameter (Figure 3).

\section{Causes}

Iron deficiency is usually not caused by a lack of Fe in the soil, but rather by poor soil aeration or by planting palms too deeply (Figures 4 and 5). Both factors reduce root respiration and therefore active uptake of Fe. Root injury from root rot diseases will similarly be expressed above ground as Fe deficiency, since the root surface area available for interception and uptake of Fe will be greatly reduced in root rotted palms. High soil $\mathrm{pH}$ is the most common cause of $\mathrm{Fe}$ deficiency in broadleaf trees and shrubs, but in palms it usually does not cause Fe deficiencies. Excessive

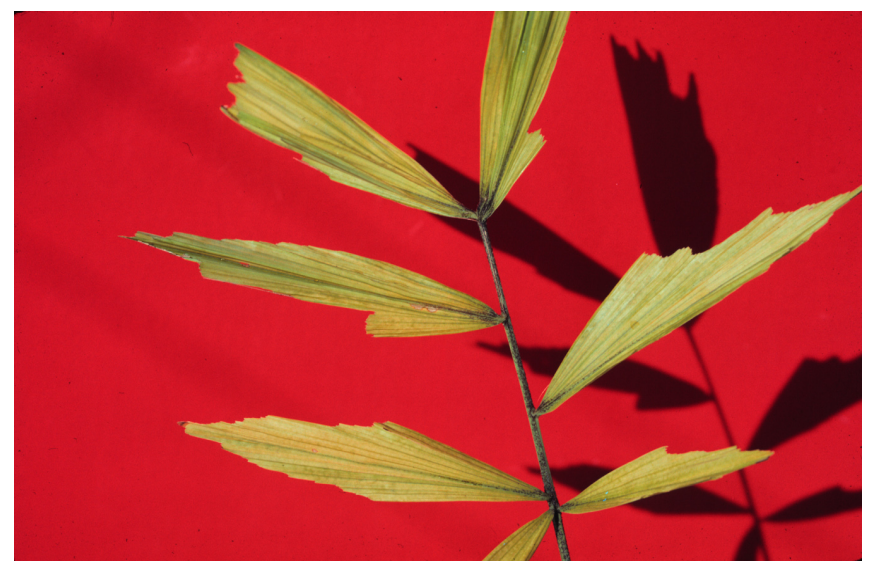

Figure 1. New leaf of Fe-deficient Caryota mitis (clustering fishtail palm) seedling. Credits: T.K. Broschat

uptake of other nutrient ions such as ammonium, phosphate, manganese, zinc, copper, and other heavy metals often results in Fe deficiency symptoms being expressed.

\section{Occurrence}

Fe deficiency is much more common in container production than in landscape or field nursery situations. Palms are typically slow-growing and may stay in a container for a year or longer. The organic components of container substrates tend to degrade into fine particles over time, reducing soil aeration in the process. Most palm species are

1. This document is ENH 1013, one of a series of the Environmental Horticulture Department, Florida Cooperative Extension Service, Institute of Food and Agricultural Sciences, University of Florida. Original publication date September 2005. Visit the EDIS Web Site at http://edis.ifas.ufl.edu.

2. Timothy K. Broschat is Professor, Environmental Horticulture Department, Fort Lauderdale Research and Education Center, Institute of Food and Agricultural Sciences, University of Florida, Fort Lauderdale, FL 33314

The Institute of Food and Agricultural Sciences (IFAS) is an Equal Opportunity Institution authorized to provide research, educational information and other services only to individuals and institutions that function with non-discrimination with respect to race, creed, color, religion, age, disability, sex, sexual orientation, marital status, national origin, political opinions or affiliations. U.S. Department of Agriculture, Cooperative Extension Service, University of Florida, IFAS, Florida A. \& M. University Cooperative Extension Program, and Boards of County Commissioners Cooperating. Larry Arrington, Dean 


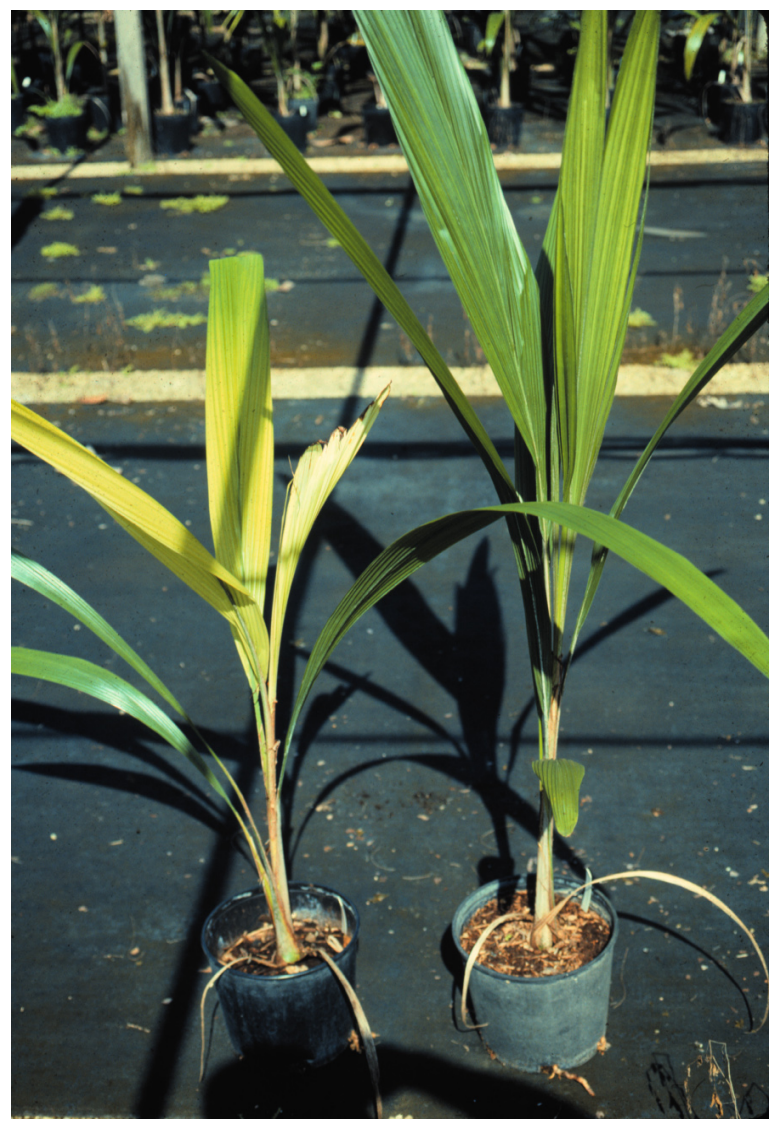

Figure 2. Severe Fe deficiency on Syagrus romanzoffiana seedling on left caused by poorly-aerated degraded potting substrate. Credits: T.K. Broschat

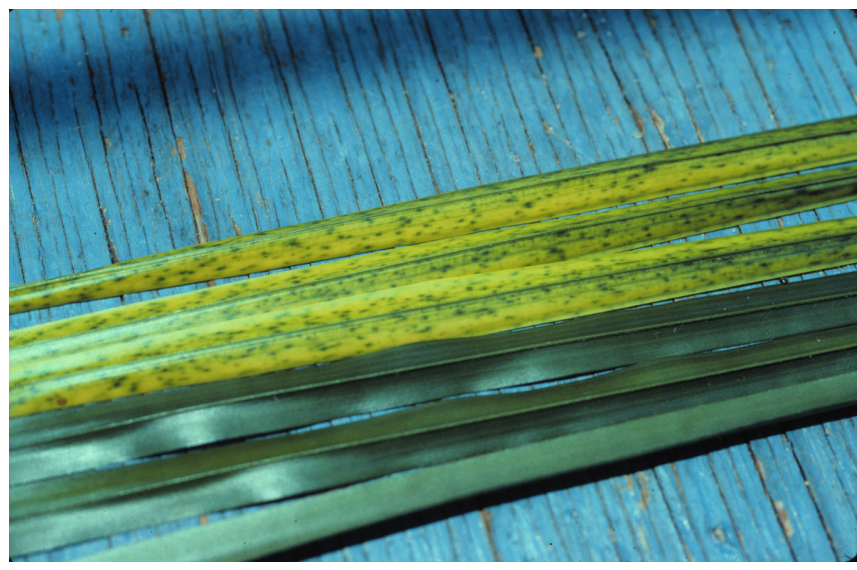

Figure 3. Top leaflets are from the youngest leaf of an Fe-deficient Syagrus romanzoffiana. Note diffuse green spots on otherwise chlorotic background. Lower leaflets are from an older leaf on the same palm. Credits: T.K. Broschat

susceptible to Fe deficiency under conditions of poor soil aeration, but Wodyetia bifurcata is particularly prone to Fe deficiency induced by high soil $\mathrm{pH}$.

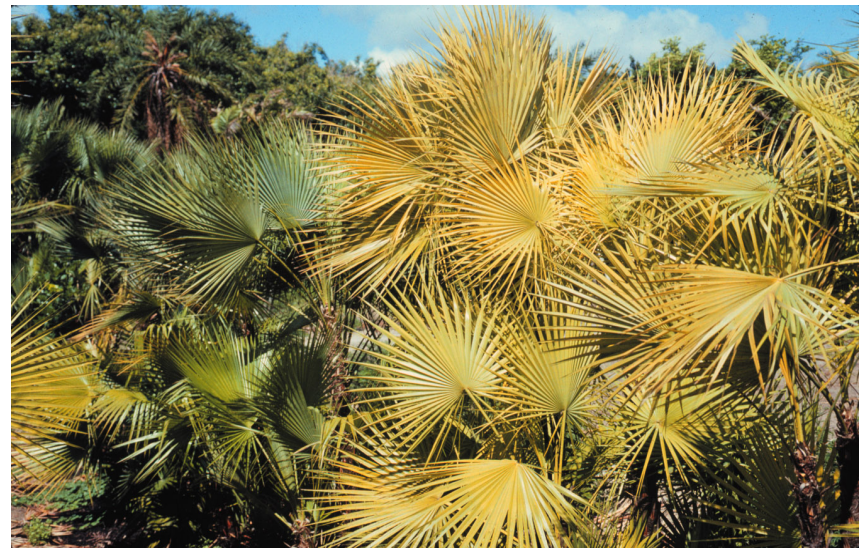

Figure 4. Chronic Fe deficiency in Acoelorrhaphe wrightii (paurotis palm) on right caused by deep planting. Credits: T.K. Broschat

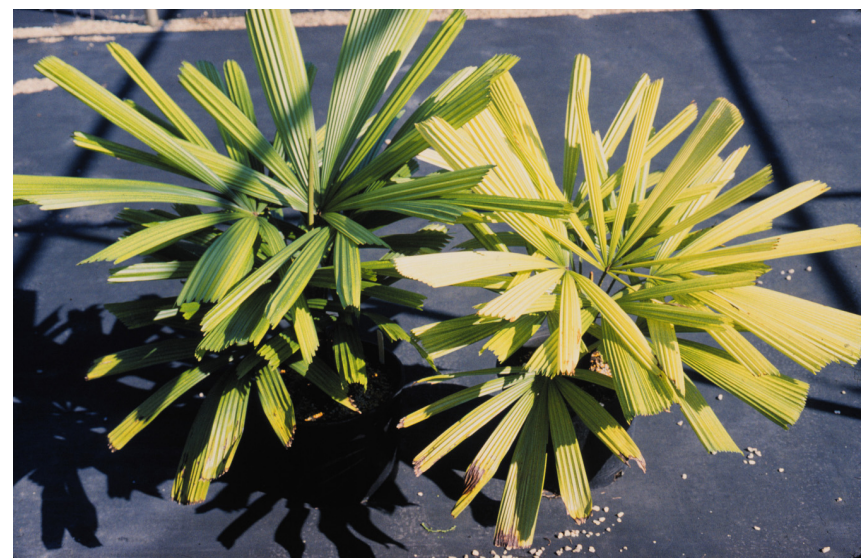

Figure 5. Chronic Fe deficiency on Licuala spinosa caused by poorly aerated decomposed potting substrate. Credits: T.K. Broschat

\section{Diagnostic Techniques}

Visual symptoms are very similar to those of sulfur (S) deficiency, thus leaf analysis would seem to be helpful in distinguishing between the two disorders. Unfortunately, leaf Fe concentrations often show little or no relation to Fe chlorosis severity and is therefore not a reliable indicator of plant Fe status. Soil analysis is not recommended for similar reasons

\section{Management}

Iron deficiency is best prevented by planting palms no deeper than they were originally growing and by planting in a well-drained soil or site. For container production, it is important that organic components used in potting substrates not only be well aerated initially, but they should also be highly 
resistant to degradation so that good soil aeration is maintained throughout the production cycle of the plant. Although treatment with Fe fertilizers can help Fe deficient palms recover, long-term recovery usually requires correction of the cultural problem that caused it in the first place.

Container-grown palms suffering from substrate degradation are best treated by removing the degraded substrate and repotting in fresh substrate. Palms planted too deeply should be dug up and replanted at the proper depth. Palms suffering from high concentrations of other heavy metals can be treated with the Fe fertilizers listed below. Unlike most other nutrient deficiencies, Fe-deficient chlorotic leaf tissue can regain its normal green color if effectively treated.

Soil applications of iron sulfate are generally less effective than some of the chelated compounds such as DTPA, EDDHA, or HEEDTA since free $\mathrm{Fe}^{++}$ions are rapidly oxidized under most soil conditions to the insoluble $\mathrm{Fe}^{+++}$form. On alkaline soils EDDHA is the most effective product, followed by HEEDTA and DTPA. FeDTPA is the most effective product for foliar application, but it is important to note that all of these chelates can be phytotoxic to palms and other plants when applied at high rates (Figure 6). Follow application guidelines on the label for these products. Most Fe fertilizers cause brown staining, so care must be taken to keep them away from non-target objects.

See also ENH1009 and ENH1010

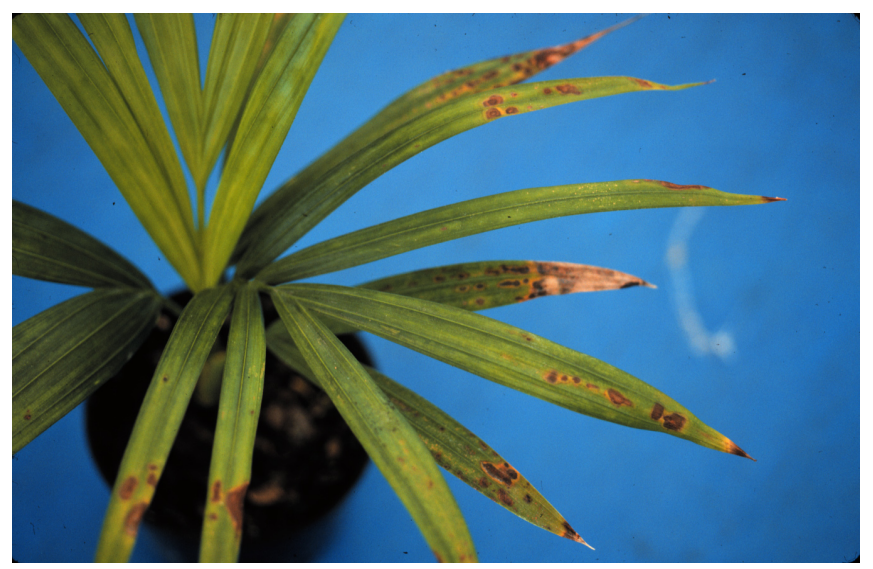

Figure 6. Iron toxicity on Dypsis lutescens (areca palm) seedling showing necrotic spotting on the foliage. Credits: T.K. Broschat

\section{Selected References}

Broschat, T.K. 1984. Nutrient deficiency symptoms in five species of palms grown as foliage plants. Principes 28:6-14.

Broschat, T.K. and H. Donselman. 1985. Causes of palm nutritional disorders. Proc. Fla. St. Hort. Soc. 98:101-102.

Bull, R.A. 1961. Studies on the deficiency diseases of the oil palm. 3. Micronutrient deficiency symptoms in oil palm seedlings grown in sand culture. J. West African Inst. Oil Palm Res. 3:265-272.

Chase, A.R. 1984. Influence of foliar applications of micronutrients and fungicides on foliar necrosis and leaf spot diseases of Chrysalidocarpus lutescens. Plant Disease 68:195-197. 